\title{
Pávai Gyula
}

\section{Vörösmarty és Arad}

Ficzay Dénes, ${ }^{1}$ az irodalmi helytörténet kimagasló aradi képviselője a fenti címszó alatt összegezte Vörösmarty aradi vonatkozásainak kutatását.

A költő Pesten ismerkedett meg Fábián Gáborral (Kultsár István házában). Fábián Gábor a húszas évek elején mint fiatal joghallgató lelkes tagja volt Kisfaludy Aurora-körének, s mint kitűnő müfordító kivívta a kör tagjainak s vezetőjének tetszését, olyannyira, hogy néhány munkája meg is jelent a zsebkönyvben. Fábián Gábor, bár unokaöccse volt a Kazinczyt bíráló Somogyi Gedeonnak, teljes mértékben az új irodalom pártján állt s lelkesen csatlakozott annak fiatal képviselöihez. Vörösmartyhoz és Bajzához baráti kapcsolat is füzte.

Amikor megtudta, hogy Vörösmarty honfoglaláskori eposzba kezdett, ő is hozzáfogott Buda haragja címmel egy hasonló költeményhez, de olvasva a készülő Zalánból belátja, hogy barátja nagyobb tehetséggel bír, s nem egészen 150 sor után felhagy a kísérletezéssel. Közben elkészül Osszián költeményeinek fordításával, amit társai jobbnak tartanak, mint Kazinczy hasonló című munkáját. ${ }^{2}$

Sokat leveleznek, így Vörösmarty pontos adatokat kap a megye érdekességeiről, az épülő város szépségeiről. Válaszaiban arra buzdítja Fábiánt, hogy költözzék Pestre, hisz tehetségével sokra viheti még. „Hagyd ott az a Perecsényi földjét” irja - ,s jer közénk, ahol barátaid vannak”.

A Vörösmarty-Fábián levelezést a századvégen Kara Győző aradi tanár rendezte, aki Fábián Lászlótól, a müfordító fiától hallotta, hogy édesapja az önkényuralom évei alatt a sok zaklatás miatt jó néhány fontos levelet megsemmisített, ezért a két barát felmutatható levelezése hiányossá vált.

Egyik cikkében Ficzay Dénes említést tesz egy kötelezvényről, amelynek csak a fotokópiáját látta. 100 forintot kért a költő, barátjától, és erről kötelezvényt adott. Fábián különben meglehetősen sok előfizetőt szerzett a Zalánra és egyéb Vörösmarty kötetekre, s levélben szabadkozik, hogy az aradiak lánglisztben fizettek, mert „itt ez kelendő áru”. Ugyancsak a levelezésből tudjuk, hogy a költő járt aradi barátjánál és annak ménesi kolnáját ${ }^{3}$ is meglátogatta, ahol először „,került kapcsolatba" a híres ménesi vörösborral. Ne is csodálkozzunk, ha Rossz bor címü versében (1844) a költő, a harmadik szakaszban a híres szőlőtermesztő helyek között Eger után rögtön az Arad-hegyaljai Ménest emlegeti:

${ }^{1} 1921-1985$.

${ }^{2}$ Ficzay Dénes kutatásai szerint Vörösmarty az éji homály kifejezést az Osszián-dalok hatására írta.

A fiatal Fábián tanulmányai végeztével Arad megyében a világosi Bohus birtokon vállal állást, Vörösmarty pedig a Tudományos Gyüjteménynél dolgozott tovább.

${ }^{3}$ présházát 
Mi szép vagy Kolna Ménes oldalán!

Borod setét mint a cigány leány,

És benne a szív édes lángja ég.

A versnek országos visszhangja lett, hiszen a refrénjében az a panasz jut kifejezésre, hogy a magyar költőnek csak hitvány savanyú lőrét kell innia. Erre megmozdult az ország. Elsőnek Eger jelentkezett, majd Arad. A költő aradi ismerősei, Csernovics Péter mácsai földbirtokos (Damjanich sógora), Szalbek György, az iratosi puszta tulajdonosa és nem utolsósorban Fábián Gábor, akinek egy leveléből tudjuk, hogy paulisi, ménesi, magyarádi borokat küldöttek Mihály napjára. A küldeményt egy vers kísérte, nem más, mint Sárosi Gyula (1816-1862), az akkor már ismert lírikus tollából, aki abban az időben az aradi bíróságon dolgozott, de a költészetet sem hanyagolta el. Példa erre az öt év múlva született Aranytrombita. A vers címe: Vörösmartyhoz, keltezése „1844 őszelő, 20,” ahogy ezt a költő későbbi, Tomory Anasztáznak ajánlott kötete is bizonyítja. Nemcsak a keltezés, de a tartalomból is néhány sor arról arról árulkodik, hogy a küldeményt névnapi ajándéknak szánták.

Mikhál, hazánknak első dalnoka!

Hogy ím jövünk, magad vagy az oka.

A második, mivel neved Mihál,

A harmadik, mivel rossz bort ivál.

A vidám tónusú vers harmadik szakaszában egy kis lokálpatrióta szemrehányás is bujkál

Ha szép a kolna Ménes oldalán,

Miért nem dícsőül lantod szép dalán?

Hallgatsz Aradról, mint a rengeteg

Gyülését is más énekelte meg.

Az utolsó sorban Sárosi nyilván Czuczor Gergely elbeszélő költeményére céloz, majd egymás után bemutatja a borokat, mindegyikre talál vidám jelzőt, borunk sötét mint a szénégető, vagy barna mint a szép leány... stb. A vers befejezése a reformkorra jellemző lelkes hazafias pátoszt sem nélkülözi:

Kezd hát borunkkal, kezdd el a tusát

És írd meg e hazának hymnuszát

$\mathrm{S}$ ha minden csepp csontodig hatott

Akkor teremtsd a dörgő szózatot

Komor lesz az, miként a zárdafal,

És lángadó, mint itt e tüzital

Vörösmarty először azon év októbe 24-én keltezett levelében köszöni a borokat és a verseket. (A levél nyilvánosan az 1889-ben Aradon Náményi Lajos által szerkesztett Sárosi-Albumban jelent meg. A szerkesztő a leveleket Sárosi Gyula lányától, özvegy Viczmándy Gizellától kapta közlésre.) 
Pest, okt. 24-én, 1844.

\section{Tisztelt barátom}

Háromszoros köszönettel tartozom önnek 1) azért, mert tudtomra, a borok küldését indítványozta, mit én korántsem tartok eredetietlennek, mint azt egy költő collegánk némely hírlapban állítja. Ki nekem jó borok küldését indítványozta, az mindenkor eredeti, tősgyökeres, becsületes, magyar ember... 2) köszönettel tartozom a borokért, amelyeket saját neve alatt küldött, de 3) mindenekfelett a versekért. Melyek mondhatni nagy örömömre voltak.

Kérem önt, jelentse egyszersmind köszönetemet mindazon uraknak, kik ily kegyes ajándékkal megtiszteltek.

A lakomára nézve egy kis felvilágosítással tartozom. Én semmiről írásban értesítve nem lévén, csak a lakomán tudtam meg, hogy a paulisi fél akó bor oda volt szánva, de akkor már oda vinni sem lehetett. Azonban vagy tíz itce aszút, s 2 liter máslást vittem hamarjában s azt jóízüen elköltöttük. Azóta egy akó magyarádit, egy akó veres bort, s egy akó ürmöst vettem át hiba nélkül: a legelső küldemény egy $1 / 2$ akó paulisi veres bor üvegekben, szinte fél akó, részint aszú, részint magyarádi. Az üvegekből csak 2 tört el, amit ezennel nyugtatvány gyanánt jegyzek ide.

A borok között igen jelesekre találtam. Vegye ön még egyszer szíves köszönetemet s üdvözölje nevemben ismerős és nem ismerős jóakaróimat. Feleletet a borokra és a versekre tán nemsokára versekben fogok mondani.

Tisztelő barátja Vörösmarty Mihály

Az ígért vers nem sokáig váratott magára. Vörösmarty mindenkinek választ adott és köszönetet mondott a küldeményekért. A vers címe - Jó bor - és benne Eger után rögtön Arad következik, s már nem a ménesi kolnairól szóló emlékéröl, de a reformeszmékhez híven az épülő, szépülő hazaszerető polgárokhoz méltó városról ír.

Egy új világ van Méneshegy alatt,

Mely gyors erővel cél felé halad.

Hegyen és síkon annyi ott a kincs:

Azt kérdezhetnéd, hogy még mije nincs?

Végig fut rajta a jövevény Maros,

$\mathrm{S}$ bár nem mind üdvös, mit vad árja hoz,

De büszke fejjel termő partinál

Egy ífju város tündérképe áll,

Tűzpont gyanánt függ e város szeme

S alatta áll az alföld szelleme.

Magyar szellem! lobogj e városon:

Magas reménnyel néz felé a hon.

Csordultig a pohár, igyunk,

$\mathrm{S}$ az istenekkel álmodunk:

Éljen! ki hátra nem marad!

Virulj fel ifju, szép Arad! 
Jellemző Vörösmarty tapintatára, hogy nyomtatás előtt a kéziratot elküldte Sárosinak a következő levél kíséretében (Első közlése a Sárosi-Albumban 1889, Arad).

Pest 1849. júl. 28.

\section{Tisztelt Barátom!}

Önnek kívánsága szerint küldöm kéziratban a Jó bor című verset s nyomtatását 10 napra halasztottam. Minden óhajtásom e versek mellett csak abban áll, vajha a borok küldői úgy meg legyenek vele elégedve, mint én boraikkal.

Csak a napokban jöttem meg faluról, hol családommal néhány hetet töltöttem, $\mathrm{s}$ ezért semmi városi nevezetességet nem írhatok azon körülményen kívül, hogy ilyenkor városban lenni unalmas dolog. Vachott Sándor már mezei gazda, igen nagy szenvedéllyel üzi a kertészséget. Egy igen szép verset írt a Magányról, s úgy hallom egyebet is dolgozgat apránkint.

Üdvözletem barátaimnak! Isten áldja önt!

Barátja Vörösmarty

(Akkor még egyikük sem tudta, hogy lesz egy szabadságharc és Vörösmarty néhány napot, Bajza Józseffel együtt mint bujdosó Fábián galsai kolnájában, majd aradi házának pincéjében tölt, hogy aztán együtt meneküljenek Szalonta felé, ahol Arannyal együtt rejtőznek, a Toldiból is ismert nádasban. S azt sem tudták, hogy Sárosi Gyulát in effigie felakasztották forradalmi verses krónikája miatt s éppen az a Vachott Sándor bujtatta, akiről Vörösmarty Mihály második levelében megemlékezik.) 